\title{
IN VITRO POLLEN GERMINATION AND POLLEN VIABILITY IN PASSION FRUIT (Passiflora spp.) ${ }^{1}$
}

\author{
TALIANE LEILA SOARES ${ }^{2}$, ONILDO NUNES DE JESUS ${ }^{3}$, \\ JANAY ALMEIDA DOS SANTOS-SEREJO ${ }^{3}$, EDER JORGE DE OLIVEIRA $^{3}$
}

\begin{abstract}
The use of Passiflora species for ornamental purposes has been recently developed, but little is known about pollen viability and the potential for crossing different species. The objective of this study was to evaluate the pollen viability of six Passiflora species collected from different physiological stages of development through in vitro germination and histochemical analysis using dyes. The pollen was collected in three stages (pre-anthesis, anthesis and post-anthesis). Three compositions of culture medium were used to evaluate the in vitro germination, and two dyes (2,3,5-triphenyltetrazolium chloride, or TTC, and Lugol's solution) were used for the histochemical analysis. The culture medium containing $0.03 \% \mathrm{Ca}\left(\mathrm{NO}_{3}\right) 4 \mathrm{H}_{2} \mathrm{O}$, $0.02 \%$ of $\mathrm{Mg}\left(\mathrm{SO}_{4}\right) .7 \mathrm{H}_{2} \mathrm{O}, 0.01 \%$ of $\mathrm{KNO}_{3}, 0,01 \%$ of $\mathrm{H}_{3} \mathrm{BO}_{3}, 15 \%$ sucrose, and $0.8 \%$ agar, $\mathrm{pH} 7.0$, showed a higher percentage of pollen grains germinated. Anthesis is the best time to collect pollen because it promotes high viability and germination. The Lugol's solution and TTC dye overestimated the viability of pollen, as all accessions showed high viability indices when compared with the results obtained in vitro.
\end{abstract}

Index terms: passion fruit, pollen germination, histochemical analysis, wild passion fruit.

\section{GERMINAÇÃO DE PÓLEN IN VITRO E VIABILIDADE POLÍNICA EM MARACUJAZEIRO (Passiflora spp.)}

RESUMO - O uso de Passifloras como plantas ornamentais é recente, e por isso pouco se sabe sobre a possibilidade de cruzamento entre diferentes espécies, bem como sobre a viabilidade polínica. O objetivo do trabalho foi avaliar a viabilidade do pólen de seis espécies de maracujazeiro coletados em diferentes estádios de desenvolvimento fisiológico por meio da germinação in vitro, bem como via análise histoquímica, por meio do uso de corantes. O pólen foi coletado em três estádios (pré-antese, antese e pós-antese). Foram comparadas três composições de meios de cultura para avaliar a germinação in vitro, e para a análise histoquímica utilizou-se de dois corantes o 2,3,5-cloreto de trifeniltetrazólio (TTC) e o lugol. O meio de cultura contendo $0,03 \%$ de $\mathrm{Ca}(\mathrm{NO} 3) .4 \mathrm{H} 2 \mathrm{O}, 0,02 \%$ de $\mathrm{Mg}(\mathrm{SO} 4) .7 \mathrm{H} 2 \mathrm{O}, 0,01 \%$ de $\mathrm{KNO} 3,0,01 \%$ de $\mathrm{H} 3 \mathrm{BO} 3$, $15 \%$ de sacarose, solidificado com $0,8 \%$ de ágar e $\mathrm{pH}$ ajustado para 7,0 , proporcionou maior percentual de grãos de pólen germinados. O melhor momento de coleta do pólen com relação à melhor viabilidade $\mathrm{e}$ à germinação é na antese. $\mathrm{O}$ corante TTC e o lugol superestimaram a viabilidade de pólen, já que todos os acessos apresentaram índice de viabilidade alto, quando comparados aos resultados obtidos in vitro.

Termos para Indexação: Maracujazeiro, germinação de pólen, análise histoquímica, espécies silvestres.

'(Trabalho 163-13).Recebido em: 05-04-2013. Aceito para publicação em: 20-11-2013.

${ }^{2}$ PhD. scholarship PNPD-CAPES, Embrapa Mandioca e Fruticultura, Cx. Postal 007, CEP 44380-000 Cruz das Almas, BA, E-mail: talialeila@gmail.com

${ }^{3} \mathrm{PhD}$ researcher, Embrapa Mandioca e Fruticultura, Cx. Postal 007, CEP 44380-000, Cruz das Almas, BA, E-mail: onildo.nunes@ embrapa.br; janay.serejo@embrapa.br; eder.oliveira@embrapa.br 


\section{INTRODUCTION}

Several wild species of Passiflora from Brazil have important traits that can be transferred for commercial passion fruit varieties, such as resistance to pests and diseases, self-compatibility and other morphological and phenological aspects related to flowering, with strong ornamental appeal. The Passion Fruit Active Germplasm Bank (AGB-Passion fruit) from Embrapa Cassava and Fruit storages contain several wild species with strong ornamental potential, such as: Passiflora suberosa Mast., P. cincinnata Mast., P. gibertti N. E. Brown, P. morifolia Mast., $P$. racemosa Brot., and P. setacea DC. These species have showy and bright flowers with different colors, including white, pink, purple, blue and red, which flower at different times of the year and possess varying leaf shapes. The Passiflora species can be used as decorative flowers, with characteristics suitable for growing in pots and they can also be used for landscaping gardens whether in fences, walls or pergolas (ULMER and MACDOUGAL, 2004).

Due to the large variability of AGB-Passion fruit, several studies have been conducted to investigate the pollen fertility of wild species for their use in artificial crossing. This information might be used to facilitate the choice of the best parents to use in crosses to maximize the rate fertilization and generation of viable seeds.

The pollen viability determination can be made using direct methods, such as the induction of in vitro (ACAR and KAKANI, 2010; ALCARAZ et al., 2011) and in vivo pollen germination (DANE and EKICI, 2011; FAKHIM et al., 2011), or indirect methods based on cytological parameters, such as color (ABDELGADIR et al., 2012; BURKE et al., 2007).

In Passiflora, crosses to produce ornamental hybrids have not been successful due to incompatibility barriers that still remain unknown, which indicates the lack of studies that might help elucidate this mechanism. Using RAPD markers Junqueira et al. (2008), showed that some putative hybrids between $P$. gibertii x P. edulis f. flavicarpa were in fact, intraspecific hybrids of $P$. gibertii. In addition, Conceição et al. (2011) observed low progress in crossing involving $P$. sublanceolata $(2 \mathrm{n}$ $=22)$ and $P$. cincinnata $(2 \mathrm{n}=18)$ as a result of the different number of chromosomes. However, some interspecific hybrids for ornamental purposes such as the BRS Roseflora (JUNQUEIRA et al., 2007), BRS Rubiflora (FALEIRO et al., 2007a) and BRS Estrela-do-Cerrado (FALEIRO et al., 2007), have been launched in Brazil.
Despite the existence of data related to pollen viability for the genus Passiflora, this viability is still restricted for few species of economic interest, i.e., $P$. edulis Sims and P. alata Curtis, and little is known about the wild species, particularly those related to ornamental purposes. This study aimed to evaluate the pollen viability of six passion fruit species collected from different physiological development stages.

\section{MATERIAL AND METHODS}

\section{Plant Material}

The pollen of Passiflora species, such as P. cincinnata Mast. (BGM322), P. edulis Sims. (BGM330), P. edmundoi (BGM046), P. galbana Mast. (BGM109), P. gibertii N. E. Brown (BGM008), and P. suberosa L. (BGM152), was used. These species belong to AGB-Passion fruit at Embrapa Cassava and Fruits, Cruz das Almas (BA), located at $12^{\circ} 39^{\prime} 25^{\prime \prime}$ south latitude and $39^{\circ} 07^{\prime} 27^{\prime \prime}$ west longitude, at an altitude of $220 \mathrm{~m}$. According to the Köppen classification, the climate is BSa, i.e., with average annual potential evapotranspiration greater than the average annual rainfall, a dry season and a summer average temperature above $22^{\circ} \mathrm{C}$ in the hottest month of the year, with an annual relative humidity of approximately $80 \%$.

\section{In Vitro Pollen Germination}

Effect of physical state of culture medium for in vitro pollen germination

To select the best culture medium for the in vitro germination of pollen grains from Passiflora, two liquid culture medium described for Passiflora species (BRUCKNER et al., 2000) and a third semisolid medium (SOARES et al., 2008) adopted for other plant species, such as banana, pineapple and bromeliads, were analyzed, as described:

M1 Medium: $0.03 \% \mathrm{Ca}\left(\mathrm{NO}_{3}\right) \cdot 4 \mathrm{H}_{2} \mathrm{O}$, $0.02 \% \mathrm{Mg}\left(\mathrm{SO}_{4}\right) .7 \mathrm{H}_{2} \mathrm{O}, 0.01 \% \mathrm{KNO}_{3} .4 \mathrm{H}_{2} \mathrm{O}, 0.02 \%$ $\mathrm{Mg}\left(\mathrm{SO}_{4}\right) .7 \mathrm{H}_{2} \mathrm{O}, 0.01 \% \mathrm{KNO}_{3}, 0.01 \% \mathrm{H}_{3} \mathrm{BO}_{3}, 5 \%$ sucrose, $\mathrm{pH} 6.5$.

M2 Medium: $0.1 \% \mathrm{Ca}\left(\mathrm{NO}_{3}\right) .4 \mathrm{H}_{2} \mathrm{O}, 0.02 \%$ $\mathrm{H}_{3} \mathrm{BO}_{3}, 5 \%$ sucrose, $\mathrm{pH} 6.5$.

M3 Medium: $0.03 \% \mathrm{Ca}\left(\mathrm{NO}_{3}\right) \cdot 4 \mathrm{H}_{2} \mathrm{O}, 0.02 \%$ $\mathrm{Mg}\left(\mathrm{SO}_{4}\right) .7 \mathrm{H}_{2} \mathrm{O}, 0.01 \% \mathrm{KNO}_{3}, 0.01 \% \mathrm{H}_{3} \mathrm{BO}_{3}, 15 \%$ sucrose, solidified with $0.8 \%$ agar, $\mathrm{pH} 7.0$.

Effect of stage flower collect for in vitro pollen germination

The pollen grains of flowers from three stages of development: pre-anthesis (one day before anthesis, or bud phase), anthesis (flower fully open) 
and post-anthesis (one day after anthesis) were distributed homogeneously on the culture medium. A sample of pollen grains from five flowers of each material was used for each plate. Notably, the pollen was collected in accordance with the natural flower opening time for each species.

After inoculation, the plates were maintained under a controlled temperature $\left(27 \pm 1^{\circ} \mathrm{C}\right)$ in the dark for 24 hours before counting the germinated pollen grains using a stereomicroscope.

To determine the percentage in vitro germination, all pollen grains were counted. The germinated pollen grains were characterized when a pollen tube with a size equal to or greater than the diameter of the pollen was observed (TUINSTRA and WEDEL, 2000).

The experimental design was completely randomized in a factorial arrangement of $3 \times 6 \times 3$ (species $\mathrm{x}$ culture medium $\mathrm{x}$ physiological stages of development) with a total of 54 treatments of four replicates, each replicate was represented by a Petri dish.

\section{Pollen Grain Histochemical Analysis}

The pollen viability analysis was conducted using 2\% Lugol's solution and a $1 \%$ solution of 2,3,5-triphenyltetrazolium chloride (TTC) diluted in $50 \%$ sucrose solution. These dyes were used to identify the most efficient to reveal the pollen viability of passion fruit. The TTC indicates the presence of active dehydrogenase enzymes (BEYHAN and SERDAR, 2008), and the Lugol's solution indicates the presence of starch (HASNUNNAHAR et al., 2012).

The pollen collected from five anthers per species was distributed on a glass slide, and one drop of the specific dye was placed onto the specimen, which was closed with a coverslip. To obtain a random sample of the stained pollen grains, scanning optical microscopy was used, counting 100 pollen grains/lamina/species with three replicates, with a total of 300 pollen grains for each dye.

The experimental design was completely randomized in a factorial arrangement of $6 \times 2$ (accessions $\mathrm{x}$ dyes) in triplicates. The viable pollen grains stained with Lugol's solution assumed a brownish color, and those stained with TTC were stained a reddish color. Those pollen grains which do not show this effect were classified as unviable.

\section{Data Analysis}

For the statistical analysis, the germination percentage and viability data were subjected to arcsine square root transformation (SORKHEH and AMINI, 2010). Subsequently, these data were subjected to analysis of variance using the $F$ test, and the means were compared using Tukey's test at $5 \%$ probability. The analyses were performed using the SAS program (SAS, 2010).

\section{RESULTS}

There was an effect for in vitro analyses $(p \leq 0.05)$ in all variables analyzed (species, culture medium and stages of flower development) and their interactions. For pollen grain viability observed by histochemical analysis, there were differences $(p \leq 0.01)$ among species, stages of flower development, dye used, and interactions, including species $\mathrm{x}$ stages of flower development, species $\mathrm{x}$ dye, and stages of flower development $x$ dye.

Considering the effect of culture medium, we observed that the M3 medium had a higher percentage of germinated pollen grains $(32.92 \%)$, which was superior to the M1 (11.57\%) and M2 medium $(5.62 \%)$, consistent with previous data concerning the pollen grain germination of passion fruit (Figure 1). Furthermore, in these culture medium, we observed the occurrence of exine breakage in many pollen grains (Figure 2A), which could reflect the physical nature of the liquid culture medium, in contrast, the observed in the M3 medium was semi-solid.

Among the species studied, P. edulis Sims. exhibited a higher percentage of pollen germination $(26.62 \%)$ and was statistically superior (Table 1). Moreover, the lowest percentage of germination was observed for P. galbana $(5.03 \%)$, as showed in the Table 1 .

As the germination of pollen of the accesses of passion fruit analyzed in relation to culture medium tested was observed the highest germination rates were obtained for $P$. edmundoi, with $59.24 \%$ germinated pollen grains in the M3 medium (Figure 3 and Figure 2B). Moreover, the lowest germination was observed in P. galbana ( $8.53 \%$ ) when inoculated in this culture medium M3 (Figure 3 and Figure 2C).

Regarding the stage of floral development, there was also a significant difference $(\mathrm{p}<0.001)$ for the percentage of pollen grains that germinated. In anthesis, the pollen germination percentage was higher $(22.67 \%)$ compared with the pollen collected from flowers in post-anthesis $(17.21 \%)$ and preanthesis $(10.23 \%)$, as shown in Table 2. Among the species, $P$. edulis Sims. and P. edmundoi exhibited outstanding pollen germination, when using anthesis pollen grains with $34.91 \%$ and $37.34 \%$, respectively, (Figure 4). Moreover, lower germination rates were 
observed in $P$. galbana $(2.05 \%)$ when using preanthesis pollen grains (Figure 4).

For the interaction stage of flower development $x$ culture medium, we observed that the germination percentage in different culture medium was influenced by the stage of flower development. The highest pollen germination rates were obtained from flowers collected at anthesis and inoculated in the M3 medium (Figure 5).

Although the difference in pollen viability was noticeable between the Passiflora species, the higher ranges of variation were observed when comparing the two dyes (Table 1). The analysis with the TTC dye showed reduced pollen grain viability for all species evaluated, ranging from 54.03\% to $73.69 \%$ when compared with Lugol's solution staining $(75.15 \%$ to $91.82 \%)$. Among the species evaluated, P. gibertii showed the lowest percentage of viable pollen grains, whereas $P$. edulis Sims. showed the highest levels of viability in both staining types (Figure 2D and 2E).

For all species, the highest percentage of viable pollen grains was observed when they were harvested at anthesis (Figure 6). The same behavior was observed for in vitro germination. For the interaction stage of flower development $\mathrm{x}$ dye, we observed that the highest and lowest percentages of viable pollen grains were obtained when the pollen was collected from flowers at anthesis and preanthesis, respectively, regardless of the dye used (Table 2).

\section{DISCUSSION}

In vitro germination in culture medium is a technique that simulates the conditions of the style-stigma, inducing germination and pollen tube growth. Each species requires a specific protocol of culture medium to obtain adequate pollen grain germination. Some authors have suggested that the culture medium should contain, in addition to carbohydrates, germination-stimulating substances, such as boric acid, calcium nitrate, potassium nitrate and magnesium sulfate (IMANI et al., 2011; KHAN and PERVEEN, 2006).

The pollen grain germination results obtained in this study for $P$. edulis Sims. were lower than those of Bruckner et al. (2000), showing a high percentage of pollen germination (58\%) at the anthesis stage in the M1 medium. The differences among these results showed that the variation among genotypes of the same species or even the growth conditions of the genetic materials greatly influence pollen grain germination.
One factor of major importance for in vitro germination is the consistency of the culture medium. Chagas et al. (2008) evaluated the influence of the concentration of agar $(0.4 \%, 0.6 \%, 0.8 \%$ and $1.0 \%)$ on the in vitro germination of pollen grains in pear cultivars (Pyrus calleryana Decne) and concluded that increasing the agar concentration increases the pollen germination. However, Luza and Polito (1985) investigated five concentrations of agar $(0.50 \%, 0.65 \%, 0.95 \%, 0.80 \%$ and $1.00 \%)$ for pollen germination in walnuts (Juglans regia L.) and observed that increasing the agar concentration inhibited pollen germination and pollen tube length.

Culture medium containing a gelling agent (agar or gelatin) has been used successfully in pollen germination in many species (JAYAPRAKASH and SARLA, 2001; KAKANI et al., 2002; KOZAI et al., 2008). According to Stanley and Linskens (1974), the gelling agent facilitates the incorporation of sucrose or other stimulants of germination and maintains constant relative humidity and suitable aerobic conditions for adequate pollen grain germination. Moreover, the liquid medium has the disadvantage of promoting the detachment of the pollen tube, which makes the evaluation of germination difficult and promotes an underestimation of gamete viability, as the pollen grain without the pollen tube is considered non-germinated. However, high agar concentrations could work as a barrier, preventing pollen tube growth (LUZA and POLITO, 1985). Bruckner et al. (2000) successfully used a Petri dish for inoculating the pollen grains of $P$. edulis Sims. in agar-free medium.

According to Loguercio (2002), burst pollen occurs as a result of increasing osmotic pressure and low cell wall resistance, resulting in a rapid influx of water into the pollen grain and a loss of soluble substances and ions in the cytoplasm, which is known as imbibition damage. This improper rehydration causes the disorganization and dehydration of membrane and pollen metabolism, lowering the pollen viability (WOLTERS-ARTS, 2002).

In breeding programs, it is essential to collect the pollen from an appropriate stage of maturation to maintain the viability and ability to germinate when the hybridization is performed. This idea is consistent with data for several species, reinforcing the notion that the highest and lowest percentages of germinated pollen grains occur during anthesis and post-anthesis, respectively (PRASAD et al., 2011). This has biological implications, as samples collected before the natural flower opening contain immature pollen, which primarily reflects a low rate of germination. Luza and Polito (1985) observed 
greater differences than those obtained in this study in English walnuts, where the pollen grains collected at one to two days before anthesis showed $0.60 \%$ germination compared with the $45.2 \%$ pollen grain germination in flowers after anthesis. In addition, in Trichosanthes dioica Roxb. the time of pollen collection significantly affected the germination percentage, as the best results were observed when germination was performed at the time of anthesis, and the worst results were observed $20 \mathrm{hr}$ after anthesis (KUMARI et al., 2009).

When using dyes for pollen viability estimating, pollen viability is considered high when greater than $70 \%$, and these percentages would not cause breeding problems in Passiflora. Several authors have proposed that the TTC test is the most reliable estimate of pollen viability, which closely mimics that observed with in vitro germination (ABDELGADIR et al., 2012; BOLAT and PIRLAK, 1999; HUANG et al., 2004).

The assessment of viability using TTC is based on the color change of the tissues in the presence of a salt solution of 2,3,5-triphenyltetrazolium chloride, which is reduced by dehydrogenase respiratory enzymes in live tissues, resulting in a red carminecolored compound called formazan (BEYHAN and SERDAN, 2008) and dead tissues that are not dyed. The TTC test has been used to estimate the pollen viability in many species. However, in some species it can produce false positive results in the viability test when compared with the results from germination tests (DAFNI et al., 2005; STONE et al., 1995). For instance, Nybom (1985) showed no significant correlation between in vitro pollen germination with the TTC staining test in blackberry species (Rubus L. subgenus rubus Watson). Furthermore, the TTC is widely used because it is a rapid and simple method. Although estimates of the viability using TCC dye were lower than with Lugol's solution, the results were higher than those obtained with in vitro tests.

Notably, the pollen grains of Passiflora typically have large amounts of lipophilic substances associated with exine (SOUZA et al., 2004) in the form of large drops (exudate) or with a fibrillar aspect between the free columellae of the reticulum, called pollenkitt (Figure 2F). According to Pacini and Hesse (2005), this substance is usually secreted by angiosperms in most entomophilous species with amoeboid or parietal tapetum and has important functions during the dispersal of pollen grains, participating in the adherence of pollen to the body of pollinators and the recognition of pollen on the stigma, as it also attracts protein molecules involved in this interaction. Moreover, these authors mention that pollenkitt has numerous other functions, such as acting as a protector to minimize dehydration and the loss of pollen viability, attracting pollinators by color and volatilizing compounds. Lersten (2004) reports that there is direct evidence that the pollenkitt and tryphine, substances produced by the exudate carpet, might be recognition factors responsible for the germination of compatible pollen or the rejection of incompatible pollen on the stigma.

Preliminary observations indicate that the dye method might overestimate pollen grain germination, while the in vitro tests tend to underestimate it (GALLETTA, 1983). According to Scorza and Sherman (1995), reactions with dyes might not show an adequate correlation with in vitro pollen germination or the ability to perform fertilization, which were confirmed in the present study. Moreover, when comparing five dyes, Abdelgadir et al. (2012) observed that only TTC (2,3,5-triphenyltetrazolium chloride) was able to distinguish viable from nonviable pollen, thereby concluding that this dye is effective for pollen evaluation for Jatropha curcas L. (Euphorbiaceae).

We suggest that in vivo germination tests should be performed to correlate in vitro pollen germination with parameters of production, such as the number of fruits and seeds, as pollen samples that seem nonviable when tested in vitro can produce an adequate percentage of seeds in vivo in the field. Thus, the results obtained in this study provided important information that can be used for planning crosses by identifying the best male parents and the best time to collect pollen grains to maximize the potential of production of viable seeds and the establishment of breeding programs of Passiflora for the ornamental market. 
TABLE 1 - Percentage of in vitro germination and pollen viability by TTC and Lugol's solution staining in different passion fruit species.

\begin{tabular}{llccc}
\hline Accessions & \multicolumn{1}{c}{ Species } & In vitro germination & TTC $^{\mathbf{1}}$ & Lugol $^{\mathbf{1}}$ \\
\hline BGM330 & P. edulis Sims. & $26.62 \mathrm{a}$ & $72.74 \mathrm{aB}$ & $91.82 \mathrm{aA}$ \\
BGM046 & P. edmundoi Sacco & $26.18 \mathrm{~b}$ & $73.69 \mathrm{aB}$ & $87.39 \mathrm{bA}$ \\
BGM322 & P. cincinnata Mast & $16.80 \mathrm{c}$ & $62.38 \mathrm{abB}$ & $86.20 \mathrm{bA}$ \\
BGM152 & P. suberosa Mast. & $16.73 \mathrm{c}$ & $64.32 \mathrm{bB}$ & $86.36 \mathrm{bA}$ \\
BGM008 & P. gibertii N. E. Brown & $8.35 \mathrm{~d}$ & $54.03 \mathrm{cB}$ & $75.15 \mathrm{cA}$ \\
BGM109 & P. galbana Mast & $5.03 \mathrm{e}$ & $56.44 \mathrm{cB}$ & $78.92 \mathrm{cA}$ \\
\hline
\end{tabular}

${ }^{1}$ Means of each treatment followed by equal letters, uppercase in the columns and lowercase in the rows, do not differ (Tukey's test, $p \leq 0.05)$.

TABLE 2 - Percentage of in vitro germination and pollen viability in different stages of flower development.

\begin{tabular}{cccc}
\hline Stages & In vitro germination & TTC & Lugol \\
\hline Anthesis & $22.67 \mathrm{a}$ & $67.78 \mathrm{aB}$ & $88.97 \mathrm{aA}$ \\
Post-anthesis & $17.21 \mathrm{~b}$ & $67.41 \mathrm{bB}$ & $84.69 \mathrm{bA}$ \\
Pre-anthesis & $10.23 \mathrm{c}$ & $60.61 \mathrm{cB}$ & $79.28 \mathrm{cA}$ \\
\hline
\end{tabular}

Least Significant Difference (Tukey's test, $p \leq 0.05$ ) $=1.34^{1}$ Means of each treatment followed by equal letters, uppercase in the columns and lowercase in the rows, do not differ (Tukey's test, $p \leq 0.05$ ).

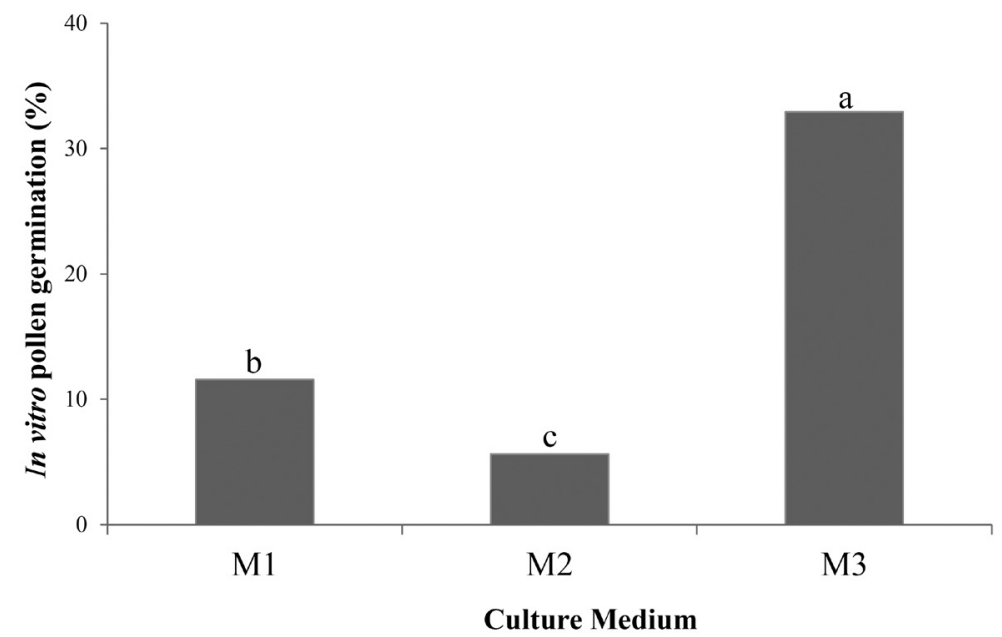

FIGURE 1 - Percentage of pollen grain germination from different culture medium. 


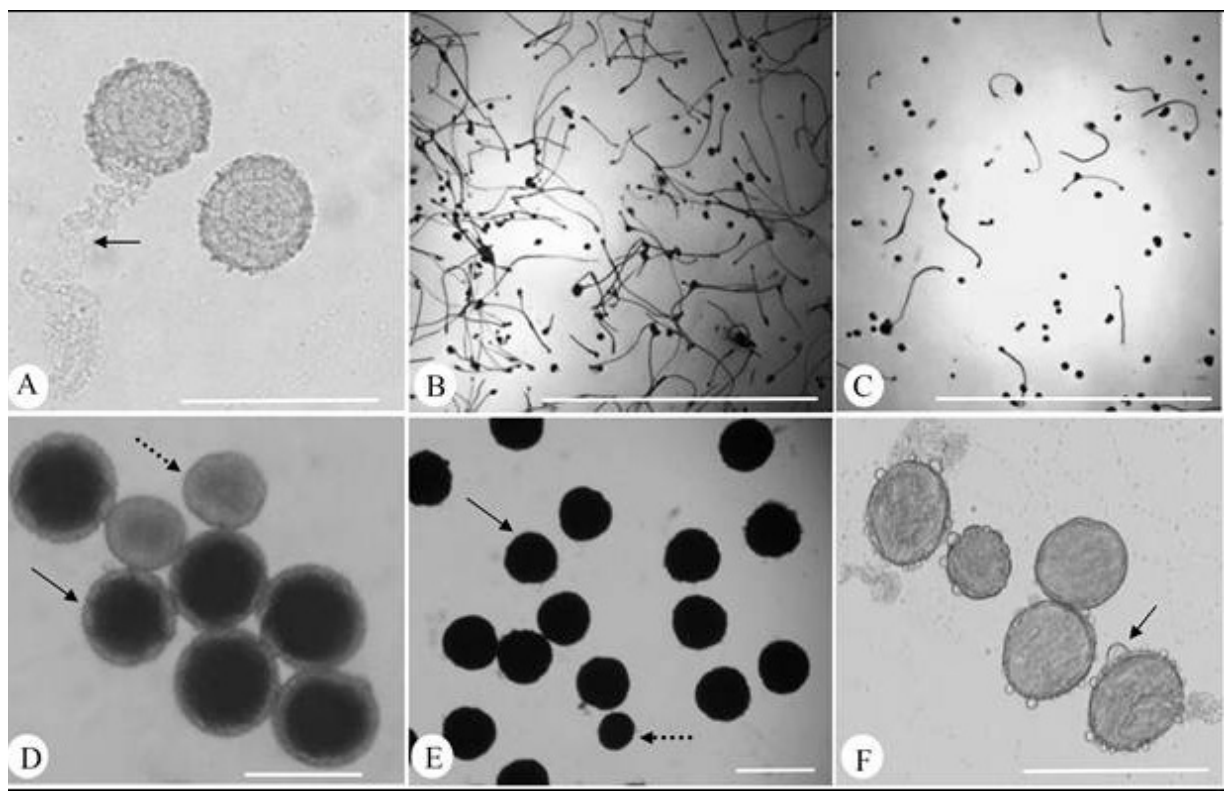

FIGURE 2 - Viability pollen grains (a-f): A) disruption of the pollen exine from BGM322 in the culture medium, B) high percentage of pollen grains germination from BGM046 in the M3 culture medium, C) low percentage of pollen grains germination from BGM109 in the M3 culture medium, D) viable pollen grains of Passiflora edulis Sims. after staining with TTC (filled arrow) and nonviable (dotted arrow), E) appearance of viable pollen grain of P. edulis Sims. stained with lugol (filled arrow) and nonviable (dotted arrow), and F) presence of pollenkitt (arrow) in BGM152 accession when grown in M1 culture medium. Scale bars: $200 \mu \mathrm{m}$ (Figure A, Figure D, Figure E and Figure F), $1000 \mu \mathrm{m}$ (Figure B and C).

-M 1 M $2 \square \mathrm{M} 3$

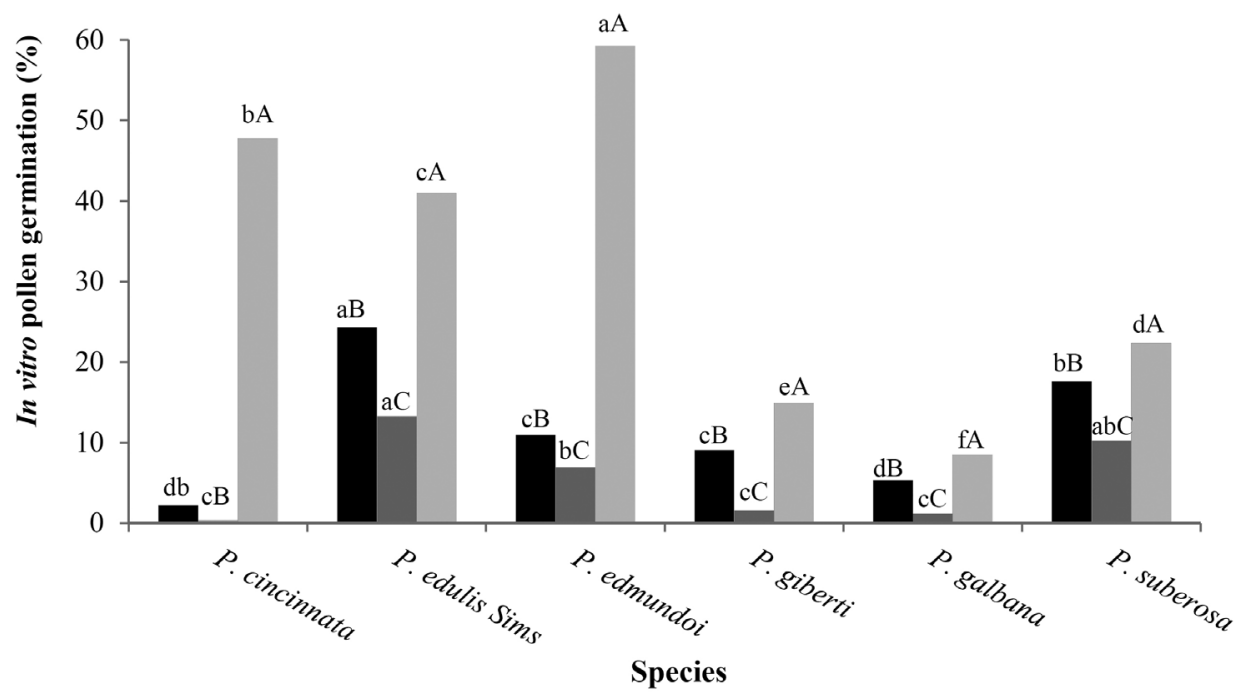

FIGURE 3 - Percentage of pollen germination in six species of passion fruit grown in different culture medium. The means indicated with the same letters in lowercase (culture medium) and uppercase (species) do not differ according to Tukey's test $(p \leq 0.05)$. 


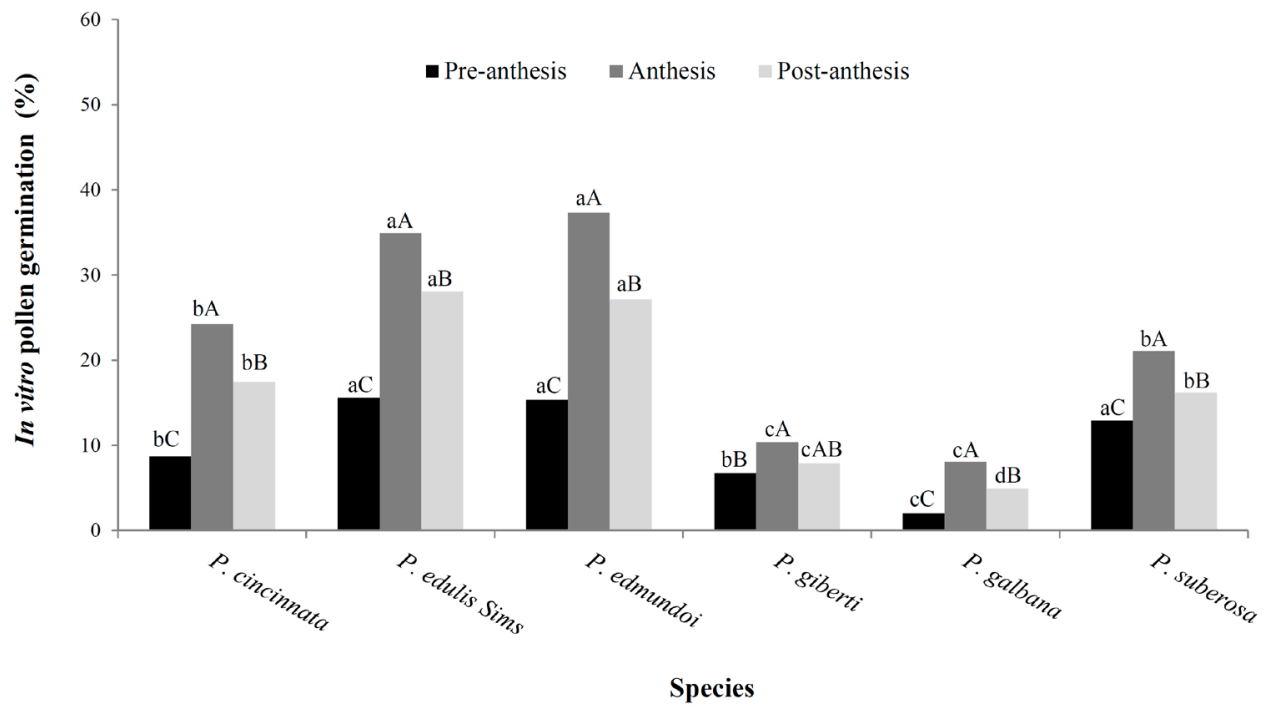

FIGURE 4 - Percentage of pollen germination in six species of passion fruit collected from different stages of flower development. The means indicated with the same letters in lowercase (stage of flower development) and uppercase (species) do not differ according to Tukey's test $(p \leq 0.05)$.

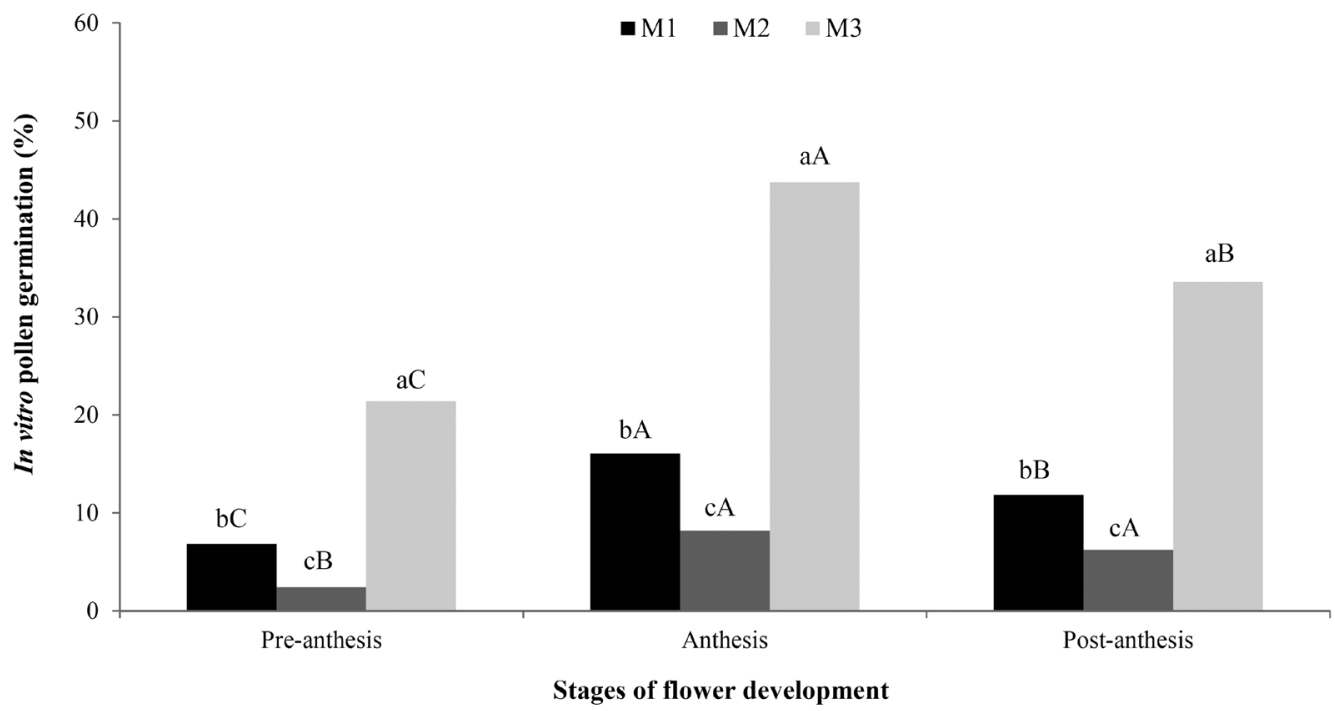

FIGURE 5 - Percentage of pollen germination collected from three stages of flower development and inoculated in different culture medium. The means indicated with the same letters in lowercase (stage of flower development) and uppercase (culture medium) do not differ according to Tukey's test $(p \leq 0.05)$. 


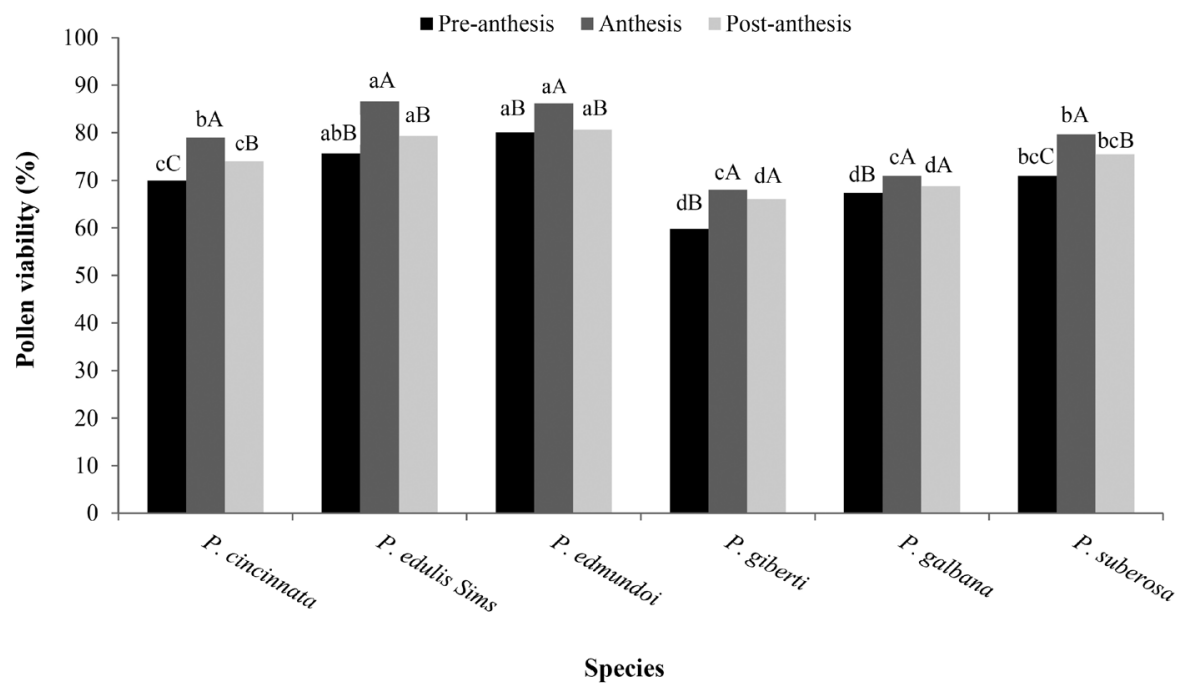

FIGURE 6- Percentage of pollen viability evaluated using staining with dyes at three stages of flower development. The means indicated with the same letters in lowercase (stage of flower development) and uppercase (species) do not differ according to Tukey's test ( $p \leq 0.05)$.

\section{CONCLUSIONS}

1-The M3 culture medium allows the better development of the pollen tube, and could be recommended as the best method to evaluate the pollen viability Passflora edulis Sims ; P. edmundoi, P. galbana, P. cincinnata, $P$. suberosa and $P$. gibertii species;

2-To maximize the potential the crosses set using Passiflora species the pollen must be collected during anthesis to be in their best physiological condition.

\section{ACKNOWLEDGEMENTS}

The authors acknowledge CNPq (National Council for Research and Development), FAPESB (Foundation for Research Support of the Bahia State) and CAPES (Coordination for Improvement of Higher Education Staff) for the fellowships and financial support.

\section{REFERENCES}

ABDELGADIR, H.A.; JOHNSON, S.D.; VAN STADEN, J. Pollen viability, pollen germination and pollen tube growth in the biofuel seed crop Jatropha curcas (Euphorbiaceae). South African Journal of Botany, Pretoria, v. 79, p.132-139, 2012.

ACAR, I.; KAKANI, V.G. The effects of temperature on in vitro pollen germination and pollen tube growth of Pistacia spp. Scientia Horticulturae, Amsterdam, v. 125 , p. 569-572, 2010.

ALCARAZ, M.L.; MONTSERRAT, M.; HORMAZA, J.I. In vitro pollen germination in avocado (Persea americana Mill.): Optimization of the method and effect of temperature. Scientia Horticulturae, Amsterdam, v.130, p. 152-156, 2011.

BEYHAN, N.; SERDAR, U. Assessment of pollen viability and germinability in some European chestnut genotypes (Castanea sativa L.). Horticultural Science, Hoboken, v. 35, p. 171-178, 2008.

BOLAT, I.; PIRLAK, L. An investigation on pollen viability, germination and tube growth in some stone fruits. Journal of Agriculture and Forestry, Rosemead, v. 23, p. 383-388, 1999. 
BRUCKNER, C.H.; SILVA, M.M.; FALLEIRO, T.M.; ANDRADE, B.B.; MOREIRA, A.E. Viability of passion fruit pollen under different storage conditions. Revista Ceres, Viçosa, MG, v. 47, p. 523-531, 2000.

BURKE, I.C.; WILCUT, J.W.; ALLEN, N.S. Viability and in vitro germination of johnsongrass (Sorghum halepense) pollen. Weed Technology, Champaign, v. 21, p. 23-29, 2007.

CHAGAS, E.A.; BARBOSA, W.; SAITO, A.; PIO, R.; CHAGAS, P.C. In vitro germination of Pyrus calleryana Decne. pollen: adjusting a protocol. Acta Horticulturae, Leuven, v.800, p. 515-520, 2008.

CONCEIÇÃO, L.D. H.C.S.; SOUZA, M.M.; BELO, G.O.; SANTOS, S.F.; FREITAS, J.C.O. Hybridization among wild passionflower species. Revista Brasileira de Botânica, São Paulo, v. 34, p. 237-240, 2011.

DAFNI, A.; PACINI, E.; NEPI, M. Pollen and stigma biology. In: DAFNI, A.; KEVAN, P.G.; HUSBAND, B.C. Practical pollination biology. Ontario: Enviroquest, 2005. p. 83-146.

DANE, F.; EKICI, N. Pollen tube growth of Paeonia tenuifolia L. (Paeoniaceae) in vitro and in vivo. Bangladesh Journal of Botany, Dhaka, v. 40, p. 93-95, 2011.

FAKHIM, R.S.H.; HAJILOU, J.; ZAARE, N.F. Pollen germination and pistil performance in several Iranian peach cultivars. International Journal of AgriScience, Münster, v. 1, p. 71-77, 2011.

FALEIRO, F.G.; JUNQUEIRA, N.T.V.; JUNQUEIRA, K.P.; BRAGA, M.F.; SOARESSCOTT, M.D.; SOUZA, L.S.; CASTIGLIONI, G.L. BRS Rubiflora: Híbrido de Passiflora para uso como planta ornamental. Revista Brasileira de Horticultura Ornamental, Campinas, v. 13, p. 337, 2007a.

FALEIRO, F.G.; JUNQUEIRA, N.T.V.; JUNQUEIRA, K.P.; BRAGA, M.F.; BORGES, R.S.; PEIXOTO, J.R.; ANDRADE, G.A.; SANTOS, E.C.; SILVA, D.G.P. BRS Estrela do Cerrado: Híbrido de Passiflora para uso como planta ornamental. Revista Brasileira de Horticultura Ornamental, Campinas, v. 13, p. 334, 2007b.
GALLETTA, G.J. Pollen and seed management. In: MOORE, J.N.; JANICK, J. (Ed.). Methods in fruits breeding. West Lafayette: Purdue University Press, 1983. p. 23-47.

HASNUNNAHAR, M.; KHAN, M.M.R.; ISSHIKI, S. Pollen and seed fertility of three functional malesterile lines of eggplant with the wild Solanum cytoplasms. Scientia Horticulturae, Amsterdan, v. 139, p.58-61, 2012.

HUANG, Z.; ZHU, J.; MU, X.; LIN, J. Pollen dispersion, pollen viability and pistil receptivity in Leymus chInensis. Annals of Botany, London, v. 93, 295-301, 2004.

IMANI, A.; KAZEM, B.; SAEED, P.; SEIYED, H.M Storage of apple pollen and in vitro germination. African Journal of Agricultural Research, Victoria Island, v. 6, p. 624-629, 2011.

JAYAPRAKASH, P.; SARLA, N. Development of an improved medium for germination of Cajanus cajan (L.) Millsp. pollen in vitro. Journal Experimental of Botany, Oxford, v. 52, p. 851-855, 2001.

JUNQUEIRA, K.P.; FALEIRO, F.G.; JUNQUEIRA, N.T.; BELLON, G.; RAMOS, J.D.; BRAGA, M.F.; SOUZA, L.S. Confirmação de híbridos interespecíficos artificiais no gênero Passiflora por meio de marcadores RAPD. Revista Brasileira de Fruticultura, Jaboticabal, v. 30, p. 191-196, 2008.

JUNQUEIRA, K.P.; JUNQUEIRA, N.T.V.; FALEIRO, F.G.; BRAGA, M.F.; LIMA, C.A.; VAZ, C.F.; VILLANOVA, A.C.C. BRS Roseflora: Híbrido de Passiflora para uso em paisagismo. Revista Brasileira de Horticultura Ornamental, Campinas, v. 13 , p. $340,2007$.

KAKANI, V.G.; PRASAD, P.V.V.; CRAUFURD, P.Q.; WHEELER, T.R. Response of in vitro pollen germination and pollen tube growth of groundnut (Arachis hypogaea L.) genotypes to temperature. Plant, Cell \& Environment, Oxford, v. 25, p. 1651-1661, 2002.

KHAN, S.A.; PERVEEN, A. Germination capacity of stored pollen of Abelmoschus esculentus L. (Malvaceae) and their maintenance. Pakistan Journal of Botany, Karachi, v. 38, p. 233-236, 2006. 
KOZAI, N.; KATAOKA, I.; CHUSRI, O.; YONEMOTO, Y.; OGATA, T. Improvement of artificial medium for passionfruit pollen germination. Acta Horticulturae, Leuven, v. 787, p. 155-158, 2008.

KUMARI, A.; KOMAL, R.; RAJESH, R.; PANDE, A.K.. In vitro pollen germination, pollen tube growth and pollen viability in Trichosanthes dioica Roxb. (Cucurbitaceae). The International Journal of Plant Reproductive Biology, Agra, v. 1, p. 147151. 2009.

LERSTEN, N.R. Flowering plant embryology. Oxford: Blackwell Publishing, 2004. 212p.

LOGUERCIO, L.L. Pollen treatment in high osmotic potential: a simple tool for in vitro preservation and manipulation of viability in gametophytic populations. Brazilian Journal of Plant Physiology, Campos dos Goytacazes, v. 14, p. 65-70, 2002.

LUZA, J.G.; POLITO, V.S. In vitro germination and storage of English walnut pollen. Scientia Horticulturae, Amsterdam, v. 27, p. 303-316, 1985.

NYBOM, H. Pollen viability assessments in blackberries (Rubus subgen. Rubus). Plant Systematics and Evolution, Vienna, v. 150, p. 281-290, 1985.

PACINI, E.; HESSE, M. Pollenkitt - its composition, forms and functions. Flora, Aschaffenburg, v. 200, p. 399-415, 2005.

PRASAD, P.V.V.; BOOTE, K.J.; ALLEN, J.R.; L.H. Longevity and temperature response of pollen as affected by elevated growth temperature and carbon dioxide in peanut and grain sorghum. Environmental and Experimental Botany, Oxford, v. 70, p. 51-57, 2011.

SAS Institute. SAS/STAT user's guide: Version 9.1.3. Cary, 2004.
SCORZA, R.; SHERMAN, W.B. Peaches. In: JANIK, J.; MOORE, J.N. (Ed.). Fruit breeding. New York: John \& Sons, 1995. p. 325-440.

SOARES, T.L.; SILVA, S.O.; COSTA, M.A.P.C.; SANTOS-SEREJO, J.A.; SOUZA, A.S.; LINO, L.S.M.; SOUZA, E.H.; JESUS, O.N. In vitro germination and viability of pollen grains of banana diploids. Crop Breeding and Applied Biotechnology, Viçosa, MG, v. 8, p. 111-118, 2008.

SORKHEH, K.; AMINI, F. Principale and procedures of multivariate statistical analysis. Tehran: Daneshparvar Press, 2010.

SOUZA, M.M.; PEREIRA, T.N.S.; VIANA, A.P.; SILVA, L.C.; SUDRÉ, C.P. Pollen viability and fertility in wild and cultivated Passiflora species (Passifloraceae). Beiträge zur Biologie der Pflanzen, Berlin, v. 73, p. 359-376, 2004.

STANLEY, R.G.; LINSKENS, H. F. Pollen biology biochemistry management. Berlin: SpringerVerlag, 1974. 307p.

STONE, J.L.; THOMSON, J.D.; DENT-ACOSTA, S.J. Assessment of pollen viability in handpollination experiments: a review. American Journal of Botany, New York, v. 82, p. 1186-1197, 1995.

TUINSTRA, M.R.; WEDEL, J. Estimation of pollen viability in grain sorghum. Crop Science, Madison, v.40, p. 968-970, 2000.

ULMER, T.; MACDOUGAL, J.M. Passiflora: passionflowers of the world. Portland: Timber Press, 2004. 430p.

WOLTERS-ARTS, M.; VAN DER WEERD, L.; VAN AELST, A.C.; VAN DER WEERD, J.; VAN AS, H.; MARIANI, C. Water-conduction properties of lipids during pollen hydration. Plant, Cell \& Environment, Oxford, v. 25, p. 513-519, 2002. 